\title{
First report on orally administered methadone to multi-drug resistance (MDR1) gene normal horses
}

\author{
Primeiro relato da administração oral de metadona em cavalos \\ normais para o gene de resistência múltipla às drogas (MDR1)
}

\author{
Cláudio Corrêa Natalini ${ }^{1}$, Nadia Crosignani ${ }^{1} \&$ Renata Lehn Linardi ${ }^{2}$
}

\begin{abstract}
Opioids are potent analgesics and are believed to be the best choice for moderate and severe nociceptive pain. Investigating all the possible administration route options for pain management in the different animal species is warranted in horses as systemic administration of these drugs in horses is difficult. In this study the authors describe for the first time in the literature the administration of methadone orally to MDR1 genotipically normal horses. Twelve adult healthy horses ( 6 females and 6 males) were studied. Horses randomly received one of the doses of methadone $(0.1,0.2$, and $0.4 \mathrm{mg} / \mathrm{kg})$ per os, which was administered using a $60 \mathrm{cc}$ syringe containing $30 \mathrm{ml}$ of corn syrup The results showed all doses produced plasma levels compatible to analgesic plasma levels in human beings. The authors conclude that methadone is absorbed when orally administered in horses at doses of $0.1,0.2$, and $0.4 \mathrm{mg} \cdot \mathrm{kg}^{-1}$. It does not produce excitement, sedation, nor undesirable side effects in healthy horses. Further studies are necessary in order to establish clinical guidelines for oral methadone as an alternative for pain management in the horse.
\end{abstract}

Key words: pharmacokinetics, methadone, horses, MDR1.

\section{RESUMO}

Os derivados opióides são analgésicos potentes e acredita-se os fármacos de escolha para tratamento da dor nociceptiva moderada ou severa. A investigação de todas as opções de vias de administração deve ser garantida no eqüino em razão das dificuldades do uso sistêmico destes fármacos nesta espécie. Neste estudo, os autores descrevem pela primeira vez na literatura a administração de metadona oral em cavalos genotipicamente normais para o gene MDR1. Foram estudados 12 eqüinos adultos (6 machos e 6 fêmeas). Os cavalos receberam aleatoriamente uma das doses de metadona $\left(0.1,0.2\right.$, and 0.4 mg.kg fer $\left.^{-1}\right)$ per os, que foram administradas utilizando-se uma seringa de $60 \mathrm{cc}$ contendo $30 \mathrm{ml}$ de xarope de milho. Os resultados demonstraram que doses variáveis de $0.1,0.2$, e $0.4 \mathrm{mg} . \mathrm{kg}^{-1}$ produzem concentrações plasmáticas similares as concentrações analgésicas obtidas em seres humanos. Estas doses não produzem excitação, sedação ou efeitos colaterais indesejáveis em eqüinos hígidos. Estudos futuros são necessários para se estabelecer as diretrizes para o uso clínico de metadona oral como alternativa para o controle da dor no cavalo.

Descritores: farmacocinética, metadona, cavalos, MDR1. 


\section{INTRODUCTION}

Pain management is advancing continuously in veterinary medicine. In equine medicine, it has been shown a relevant clinical importance in shortening and improving recovery of animals in trauma, for surgical patients, and in the postoperative period $[1,3,11$, 13]. However, the restriction of some currently available analgesic agents due to limited efficacy and risk of undesirable side effects impairs in providing an effective analgesia for acute or prolonged pain in horses $[1,3]$.

Opioids the most effective analgesic known, are recognized to be able to treat moderate to severe pain, persistent or chronic pain, and neuropathic pain as well [7]. However, opioid drugs may induce central nervous system (CNS) excitation, respiratory depression, decrease of gastrointestinal motility, and increase of locomotor activity when used alone systemically in horses [5].

Methadone is an opioid which has high oral bioavailability (>70\%) and long elimination half-life (>20 hours) in human beings [9]. Oral methadone has been widely studied in human medicine as an alternative route to systemic administration of opioids. Strongly recommended as elective treatment for cancer pain, oral methadone is associated with minimum or few intensive side effects in people [2]. Methadone hydrochloride is a synthetic $\mu$-opioid receptor agonist $\left(\mathrm{OP}_{3}\right.$ agonist) approximately equipotent to morphine in terms of analgesia [2]. Unlike other opioid drugs, methadone is also an N-methyl-D-aspartate (NMDA) receptor antagonist and functions as a norepinephrinereuptake inhibitor. These particular characteristics may enhance the analgesic efficacy of methadone when compared to other therapeutic drugs [12].

The pharmacokinetics and pharmacodynamics of methadone are a complex process and still not completely understood especially in the horse. In a single study of intravenous methadone administered to horses individual variation was similar to humans [8].

Considering the high analgesic efficacy of oral methadone reported in people and the lack of information regarding pharmacokinetics of oral opioids in horses, the purpose of this study was to determine the pharmacokinetic of methadone administered orally to horses.

\section{MATERIAL AND METHODS}

Twelve adult healthy horses (6 females and 6 males) were studied. Weighing from $443 \mathrm{~kg}$ to $577 \mathrm{~kg}$
$(499 \mathrm{~kg} \pm 21)$, horses were considered free of pain due to physical evaluation. All animals had an oral biopsy performed in order to determine their status regarding the MDR1 gene according to a technique previously described [10].

Horses randomly received one of the doses of methadone $^{1}\left(0.1,0.2\right.$, and $\left.0.4 \mathrm{mg} \cdot \mathrm{kg}^{-1}\right)$ per os, which was administered using a $60 \mathrm{cc}$ syringe containing $30 \mathrm{ml}$ of corn syrup. Horses were not fasted before methadone administration. Blood samples were collected through a 14-gauge catheter previously placed on the left jugular vein in order to measure the concentration of methadone in the serum of horses. Blood $(10 \mathrm{ml})$ was collected during 24 hours, before $(0)$ and after oral administration, at 15 and 30 minutes, 1, 2, $3,4,5,6,9,12$, and 24 hours to complete evaluation.

Methadone serum concentrations were quantified using Gas Chromatography/Mass Spectrometry (GC/MS) analysis performed by Agilent Technologies 6890 Series GC System with a 5973 MS Detector with electron impact ionization ${ }^{2}$. Chromatographic data were processed using the Agilent ChemStation software ${ }^{3}$. Serum concentrations were determined by producing a calibration curve using the peak area ratios of the analyte (methadone, $294 \mathrm{~m} / \mathrm{z}$ ) to the internal standard (methadone- $d_{3}, 297 \mathrm{~m} / z$ ). Results were statistically compared with ANOVA tests and Bonferroni comparison test when $\mathrm{p}<0.05$.

\section{RESULTS}

No evidence of sedation, excitation or other undesirable side effect was observed in the horses during 24 hours of study. All three doses used (0.1, $0.2,0.4 \mathrm{mg} / \mathrm{kg}$ ) showed similar curve response. The mean peak of methadone ranged between 30 and 60 minutes, and the lowest dose $\left(0.1 \mathrm{mg} \cdot \mathrm{kg}^{-1}\right)$ produced significantly lower serum concentration from 15 to 120 minutes. After 360 minutes of administration of any of the three doses, no methadone serum levels were detected (Figure 1).

\section{DISCUSSION}

The highest detected concentration of methadone $(30.93 \mathrm{ng} / \mathrm{ml})$ after administration of the lowest dose, $0.1 \mathrm{mg} / \mathrm{kg}$, was similar to the minimal therapeutic concentration of methadone for acute pain in human beings $(33 \mathrm{ng} / \mathrm{ml})$ [6]. Interesting enough, low or none 


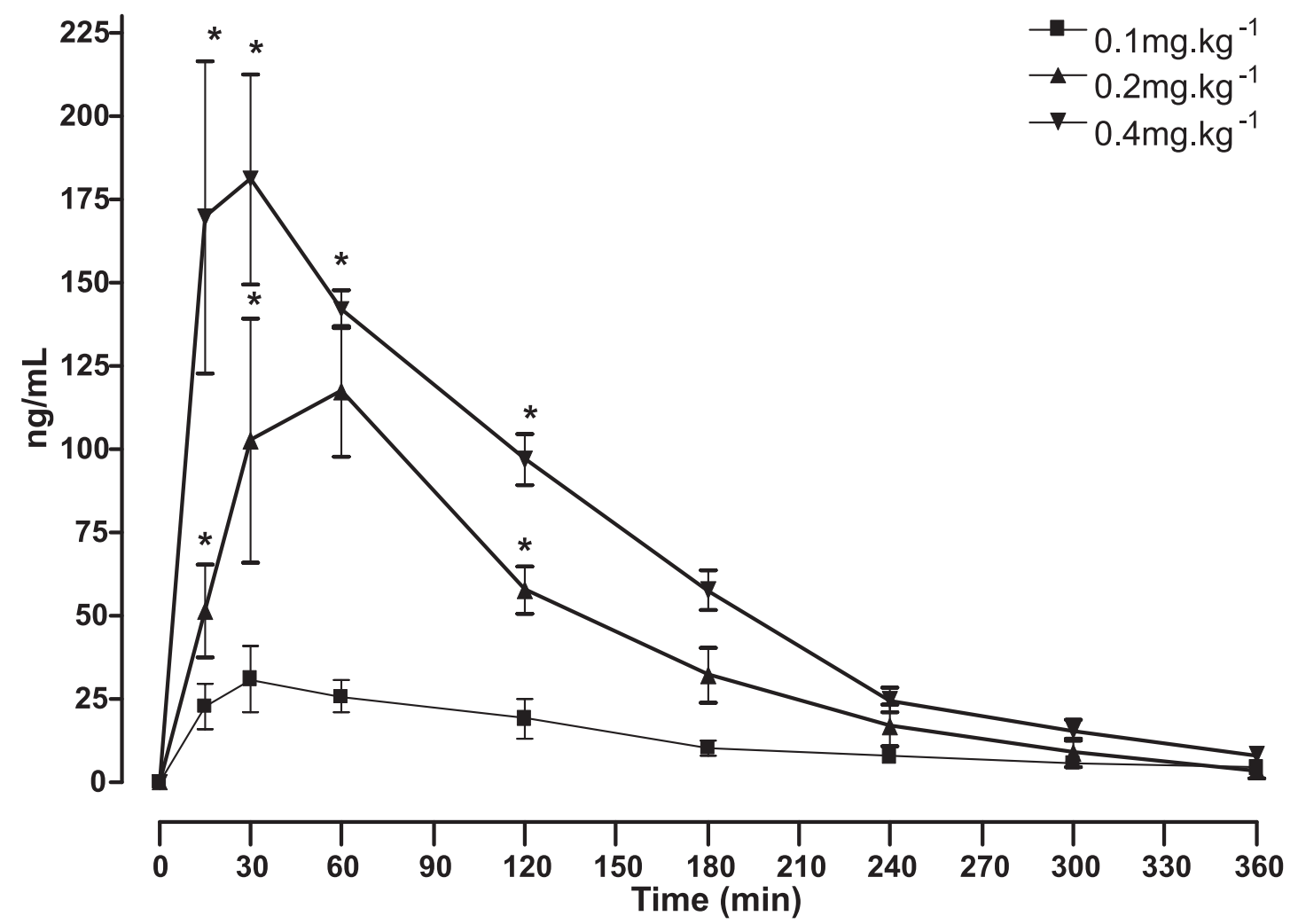

Figure 1. Time (minutes) vs. concentration ( $\mathrm{ng} / \mathrm{ml}$ ) showing the mean $\pm \mathrm{SD}$ serum concentration curve of 3 doses of methadone $(0.1,0.2,0.4 \mathrm{mg} / \mathrm{Kg})$ administered by oral route in horses.

"Significantly different from 0.2 and $0.4 \mathrm{mg} \cdot \mathrm{kg}^{-1}$.

methadone plasma levels were detected in MDR1 gene normal dogs after oral administration of similar doses of methadone [9]. Methadone is biotransformed mainly by the cytochrome P-450 (CYP3A4) and in minor importance, CYP2C8 and CYP2D6. Studies in man and dogs, suggest that the multi-drug resistance (MDR1) gene and P-glycoprotein (p-gp), enrolled in the protective mechanism of the body, play a role in the disposition of orally administered methadone [4,9]. All horses in this study were genotipically normal for the MDR1 gene.

The oral methadone behavior demonstrated a dose-dependent curve, inferring good absorption and distribution when administered by oral route in horses, without side effects. These results can be explained similarly to what is seen in human beings. The pharmacokinetics of methadone is characterized by excellent oral absorption and higher oral bioavailability (70$100 \%)$, compared to morphine (26\%). With long duration of action (6-8 hrs) and long elimination half-life (20-24h), the therapeutic blood concentrations of methadone for acute pain in people were reported to range between $33 \mathrm{ng} / \mathrm{ml}$ and $59 \mathrm{ng} / \mathrm{ml}$ when an oral dose of $0.1 \mathrm{mg} . \mathrm{kg}^{-1}$ is used [2]. We obtained similar dose-response curves although antinociception was not evaluated.

\section{CONCLUSIONS}

In conclusion, methadone is absorbed when orally administered in horses at doses of 0.1, 0.2, and $0.4 \mathrm{mg} / \mathrm{kg}$. It does not produce excitement, sedation, nor undesirable side effects in healthy horses. Oral administration of methadone may be considered safe and a viable route for horses. Further studies are necessary in order to establish clinical guidelines for oral methadone as an alternative for pain management in the horse. This study was conducted at the Louisiana State University, School of Veterinary Medicine and approved by the Louisiana State University Institutional Animal Care and Use Committee.

\section{SOURCES AND MANUFACTURERS}

${ }^{1}$ Methadone. Methadone Hydrochloride $10 \mathrm{mg}$ per $\mathrm{mL}-$ Alpharma, Inc; Lincolnton, NC, EUA

${ }^{2}$ Agilent Technologies, Wilmington, Delaware, EUA.

${ }^{3}$ Agilent Technologies, Wilmington, Delaware, EUA. 


\section{REFERENCES}

1 Bennett R.C. \& Steffey E.P. 2002. Use of opioids for pain and anesthetic amangement in horses. Veterinary Clinics of North America: Equine Practice. 18: 47-60.

2 Boulton D.W. et al. 2001. Pharmacokinetics and pharmacodynamics of methadone enatiomers after a single oral dose of racemate. Clinical Pharmacology \& Therapeutics. 70 (Suppl 1): 48-57.

3 Clarke K.W. \& Paton B.S. 1988. Combined use of detomidine with opiates in the horse. Equine Veterinary Journal. 20 (Suppl 1): 331-334.

4 Collaghan R. \& Riordan J.R. 1993. Synthetic and natural opiates interact with P-glycoprotein in multidrug-resistant cells. The Journal Biological Chemistr. 268 (Suppl 21): 16050-16064.

5 Combie J., Dougherty J., Nugent C.E. et al. 1979. The pharmacology of narcotic analgesics in the horse. IV. Dose and time response relationships for behavioral responses to morphine, meperidine, pentazocine, anileridine, methadone, and hydromorphone. Journal of Equine Medicine and Surgery. 3: 377-385.

6 Eap C.B. et al. 2002. Interindividual variability of the clinical pharmacokinetics of methadone. Clinical Pharmacokinetics. 41 (Suppl 14): 1153-1193.

7 Fleckenell P. \& Waterman-Pearson A. 2000. Pain management in animals. Philadelphia: Saunders, 184p.

8 Hagedorn H.W. et al. 1999. Methadone screening of racehorses. Journal of Analytical Toxicology. 23 (Suppl 7): 609-614.

9 Kukanich B. et al. 2005. The effects of inhibitin cytochrome P450 3A, p-glycoprotein, and gastric secretion on the oral bioavailability of methadone in dogs. Journal of Veterinary Pharmacology and Therapeutics. 28 (Suppl 5): 461-466.

10 Natalini C.C. \& Linardi R.L. 2006. Identification of multi-drug resistance gene (MDR1) in equine ileum. Ciência Rural. 36 (Suppl 1): 330-335.

11 Sellon D.C. et al. 2004. Effects of continuous rate intravenous infusion of butorphanol on physiologic and outcome variables in horses after celiotomy. Journal of Veterinary Internal Medicine. 18 (Suppl 4): 555-563.

12 Shimoyama N. et al. 1997. D-Methadone is antinociceptive in the rat formalin test. The Journal of Pharmacology and Experimental Therapeutics 283 (Suppl 2): 648-652.

13 Taylor P.M. et al. 2002. Diagnosing and treating pain in the horse. Where are we today? Veterinary Clinics of North America: Equine Practice. 18 (Suppl 1): 1-19. 